CASE REPORT

\title{
Medical Rehabilitation of Glioblastoma Multiform: Case Report
}

\section{Tanti Ajoe K, Martin}

Department of Physical Medicine and Rehabilitation, Dr. Kariadi Hospital, Faculty of Medicine University of Diponegoro, Semarang.

\begin{abstract}
Introduction: Glioblastoma Multiform (GBM) is the most common malignant primary brain tumor. Early rehabilitation program is needed to increasing the independency and the quality of life.

Methods: Case presentation of a woman, age 31 years, diagnosed with GBM. Subject has chronic headache by visual analog scale (VAS) was 5 to 6 and progressive of vision loss $(0 / 0)$, short and intermediate memory loss, the average of limb strength by manual muscle test were four, and immobilization on bed since one and half year. The first day after craniotomy, patient has Rehabilitation Program; cryotherapy for decreased the pain, therapeutic exercise, and cognitive stimulation exercise for 5 week.

Results: After 5 weeks of rehabilitation program, patient has reduced the pain measured by VAS was 0 , improved the memory, and be able to ambulation

Conclusion: Patient post GBM post craniotomy need to have comprehensive rehabilitation program to reduce pain, improve memory and ambulation.
\end{abstract}

Keywords: Glioblastoma Multiform, Rehabilitation Medicine Program 


\begin{abstract}
ABSTRAK
Pendahuluan: Glioblastoma Multiform (GBM) adalah tumor otak promer yang paling sering. Program rehabilitasi dini diperlukan untuk meningkatkan kemandirian dan kualitas hidup.

Metode: Presentasi kasus seorang wanita, umur 31 tahun, didiagnosis dengan GBM. Subjek memiliki sakit kepala kronis dengan Skala Visual Analog (VAS) 5 hingga 6 dan kehilangan penglihatan progresif $(0 / 0)$, kehilangan memori pendek dan intermediate, kekuatan tungkai rata-rata dengan test otot manual adalah empat, dan imobilisasi pada tempat tidur sejak satu setengah tahun lalu. Hari pertama setelah kraniotomi, pasien memiliki Program Rehabilitasi; krioterapi untuk menurunkan nyeri, latihan terapetik, dan latihan stimulasi kognitif selama 5 minggu.
\end{abstract}

Hasil: Setelah 5 minggu Program Rehabilitasi, pasien mengalami penurunan nyeri VAS 0, perbaikan memori, dan dapat melakukan ambulasi.

Kesimpulan: Pasien pasca GBM pasca kraniotomi perlu menjalani program rehabilitasi komprehensif untuk mengurangi nyeri, mengembalikan memori dan meningkatkan ambulasi.

Kata kunci: Glioblastoma Multiform, Program Rehabilitasi Medik

\section{Correspondent Detail:}

\section{Tanti Ajoe K}

Email: marthin.jan18@gmail.com

Department of Physical Medicine and

Rehabilitation,

Dr. Cipto Mangunkusumo Hospital,

Faculty of Medicine, University of Indonesia

Jakarta, Indonesia

\section{INTRODUCTION}

Glioblastoma (GBM) is the most aggressive diffuse gliomas of the astrocytic group and is considered a class IV gliomas based on the WHO classification. ${ }^{1}$ GBM is the most common malignant primary brain tumor and is found in $54 \%$ of all gliomas and $16 \%$ of all primary brain tumors. ${ }^{2}$ GBM remains a tumor that cannot be cured with an average survival of only 15 months with a very complex treatment, initially consisting of a maximum surgical resection followed by radiation therapy (RT) and chemotherapy Temozolomide (TMZ) together. ${ }^{3,4}$ The average annual incidence rate of GBM is 3.19 per 100,000 people in the United States, with GBM rate of 2.5 times higher in European Americans than African Americans. ${ }^{5-12}$ GBM is mainly diagnosed at an older age with an average age of 64 years. ${ }^{2,13}$ The incident increased with a peak at the age of 7584 years and decreased after 85 years. Ages when diagnosed tend to be higher for primary GBM (age 55 years and an average age of 64 years) than secondary GBM (average age of 40 years). GBM rarely occurs in children. ${ }^{2-14}$

According to the WHO classification 2016 of CNS tumors, GBM can be divided into the following 
groups: I. GBM, IDH-wild type (approximately $90 \%$ of cases) are most commonly associated with primary and dominant GBM in patients over 55 years. II. GBM, IDH-mutan (about 10\% of cases) is closely related to secondary GBM and is more common in younger patients. III. GBM, NOS..$^{5,15}$

Factors related to the risk of GBM are radiation, susceptibility to allergies, immune factors and immune genes, as well as some nucleotide polymorphisms, detected by the Genome-wide association. ${ }^{16,17}$

Surgery remains a critical component of GBM management. Surgery allows histological confirmation of a clinical diagnosis and also has a decompressive and cytoreductive effect, with the benefit of improved survival by complete resection. ${ }^{18}$

\section{CASE REPORT}

Woman patient complained of headache in all area since one and half year ago. The headache felt throbbing pain that occurred once a week. It can relieve when taking the pain killer and rest. Beside the headache, she also complained about dizziness and vomiting. One year ago, she started feel the weakness in her both limbs. She also complained about her memory that being disturbed more frequent. Moreover, there was a fever without any causes and there was a weight loss. There were no dysarthria, behavioral changes, and history of seizure.

Six month ago, she felt the headache more frequent in a week. The weakness of the limbs was also increased. She complained that her vision had become blurry and getting worse over the time. She came to ophtamologist and reffered to the neurologist in Rembang. She performed MRI and diagnosed with the brain tumor. She and her family refused to be reffered to neurosurgeon.

Two weeks before entering the hospital, she felt the headache became worse accompanied with vomiting without nausea. She also felt the weakness of her limbs more severe. She was hospitalized for 3 days in RS. Rembang, then reffered to RSDK.

She denied any hypertension, diabetes, and a history of head trauma. There was no history of tumor or cancer in family. Her social economy was low to middle class.

\section{Physical Examination}

On the general examination, it found she was Compos Mentis with GCS 15, VAS 5 to 6 . The blood pressure was $120 / 80 \mathrm{mmHg}$, heart rate $80 \mathrm{x} / \mathrm{min}$, respiratory rate $20 \mathrm{x} / \mathrm{min}$, temperature $36,6^{\circ} \mathrm{C}$. Body height was $156 \mathrm{~cm}$ with weight $46 \mathrm{~kg}$. Her face is symmetric. There is no pale in conjunctiva, icteric in sclera, pupil were symmetric $3 \mathrm{~mm}$. Ears, nose, and throat were normal. There were no palpable lymph nodes on the neck. The examination of the chest and abdomen were normal.

For the Neuromuscular Status of the patient, there was no aphasia or dysarthria. She had shor-term and immediate memory loss. She could smell well. Her vision were 0 (OD) and 0 (OS), direct and indirect light reflexes $+/+$ slower, the eyeball movement were good in all direction. There were no troubles in cranial nerve N.I, N.III-N.XII. 
The extremities were eutrofi with normal muscular tone. Motoric strength of the limbs were 4444/4444/4444/4444. Protopathic and proprioseptive examination were within normal limits. The vegetative function was within normal limits. Physiological reflex examination were Biceps $+2 /+2$, Triceps $+2 /+2$, Brachioradialis $+2 /+2$, Patella $+2 /+2$, Achilles $+2 /+2$. There were no pathological reflex.

\section{Supporting Examination}

\section{MRI}

Solid mass inhomogeneous form lobulated on left frontal lobe (size \pm AP $7.03 \mathrm{~cm}$ x LL 6.02 $\mathrm{cm} \times \mathrm{CC} 6.04 \mathrm{~cm}$ ) accompanied by necrotic area, intratumoral bleeding, perifocal edema, with midline shifting to right $( \pm 1.2 \mathrm{~cm})$ and despot Lateral ventricular from right to left.

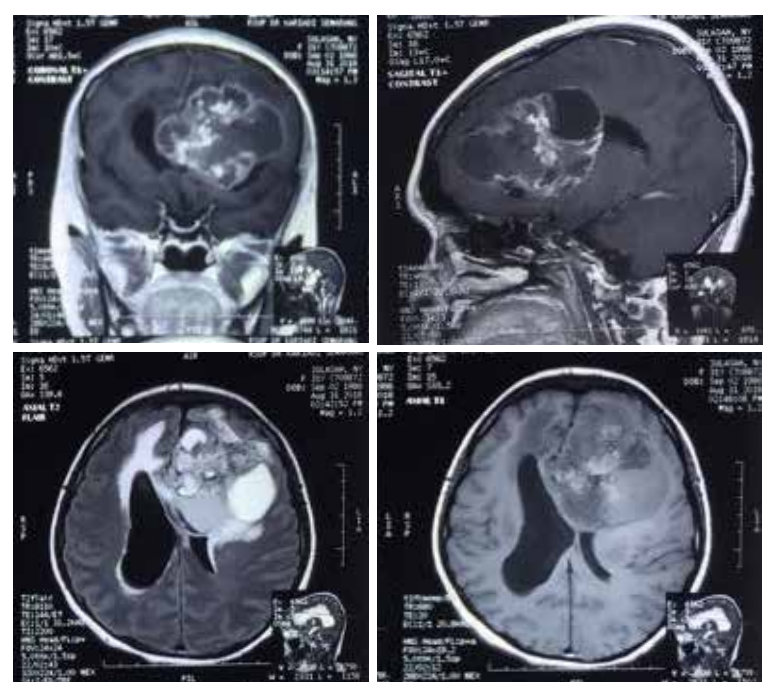

Figure 1. MRI with Contrast (31 ${ }^{\text {st }}$ August 2018)

Thorax X-Ray (AP) (26 ${ }^{\text {th }}$ August 2018)

Cor and Pulmo in normal. There were no image of metastatic or other abnormalities.

\section{Diagnosis}

Diagnosis of functions according to International Classification of Functioning, Disability and Health (ICF): Intrinsic Tumor of the province of Sinistra, bilateral Nervus II dysfunction.

Body functions are chronic Cephalgia, bilateral Hemiparesis, impaired function of bilateral vision, and impaired memory.

Activity Factor is an ambulation disorder, self care disorder (bathing, toileting, feeding).

Participation Factor is a limitation in household activities, occupations, community and religious activities. Enviromental Factor is a dependency on family/cargiver, requiring aids in mobilization, uneven surface of the ground floor. Personal Factor is a sad against illness.

\section{Objective of Medical Rehabilitation Program}

For short term were to Reduces pain and edema postoperative target VAS 0-1;.Improve muscle strength, endurance, and ROM; able to ambulation (sit-stand independently-walking short distances); able to some of self-care (bathing, toileting, dressing, combing the hair, eating and drinking); Improving the fitness/ fitness level of patients.

Long term Goals were to Improve cognitive function (memory); Ambulation in the house and around the house with vision limitation (by stimulation of proprioceptive and balance); Improve patient's psychological condition of illness; Return to work with modification of the type of work corresponding to the condition; Re-activity in the community. 
The criotherapy has used to reduce pain and edema patient receive.

The therapeutic exercises were stretching and strengthening for both limbs to increase limb muscle strength. Active range of motion (ROM) have done to prevent stiffness and contractures on the upper limb and lower limbs. Prevent complications from prolonged bed rest and improve patient functional in mobilizing the rehabilitation program provided proper body positioning, mobilization and gradual ambulation according to patient's condition and increased sensibility (proprioceptive excercise) for both limbs. We recommend using wheel chair to help her mobilize outside the house until it adapts to impaired vision. Education of family members is done with motivate the family to assist/support her in completing the treatment program to complete and help train her in order to be independent in ADL and can re-interact socially with the community. To improve the psychological condition of her, we provide the program like consultation with the psychologist, giving mental support and motivation to keep regular exercise and control and involved the family for supported and stimulation.

Patient has undergone the cranitomic surgery on the 5th September, 2018 and carried out the anatomical pathology of tumor tissue with the conclusion of a figure of the leaning of a Glioblastoma Multiforme (WHO Grade IV).

\section{Rehabilitation program after craniotomy}

\section{The $1^{\text {st }}$ day}

She complained pain of the incision surgery, VAS 4-5/10. She was still bedridden, superior extremities and inferior can be moved actively, there were no changes in muscle strength and
ROM. She was assisted for lying on the left and right side .

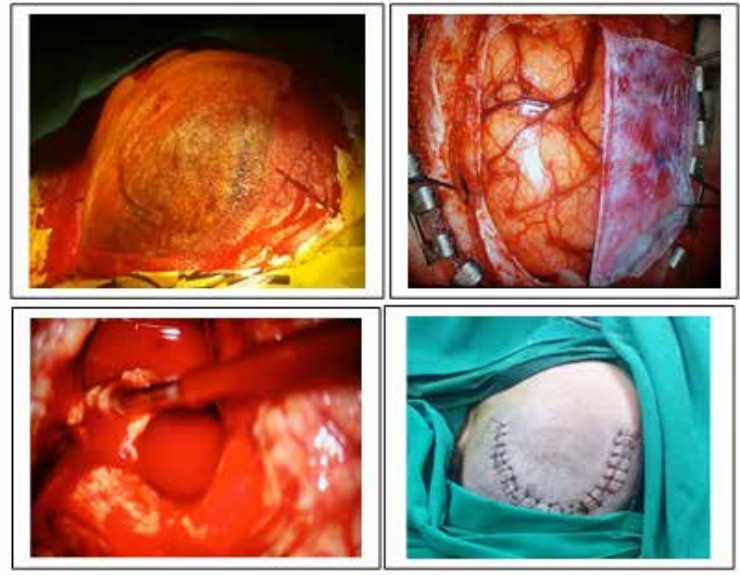

Figure 2. Pre, Durante and Post Operation Results

\section{The $2^{\text {nd }}$ day}

Pain scale was VAS 3-4/10 for post surgical incision pain. VOD/VOS 0/0. Range of motion of the lower extremity was increased. She could tilt on the left and right side independently.

\section{The $10^{\text {th }}$ day}

She was able to sit independently. Memory was still not recovered. She was allowed to going home. Surgery pain was minimal.

\section{The $5^{\text {th }}$ Week}

She could sit and stand independently. She walked assisted in about 5-10 meters. Her memory has improved (remembering the names of husbands and her children). The patient can only see the light. There was no pain. Upper and lower extremity muscle strengths were improved (55555/55555/5555/5555) with full-active ROM. Some ADL were by herself (bathing, toileting, grooming). Sometimes using wheelchairs to mobilization around the house. She was already in chemotherapy programs. 


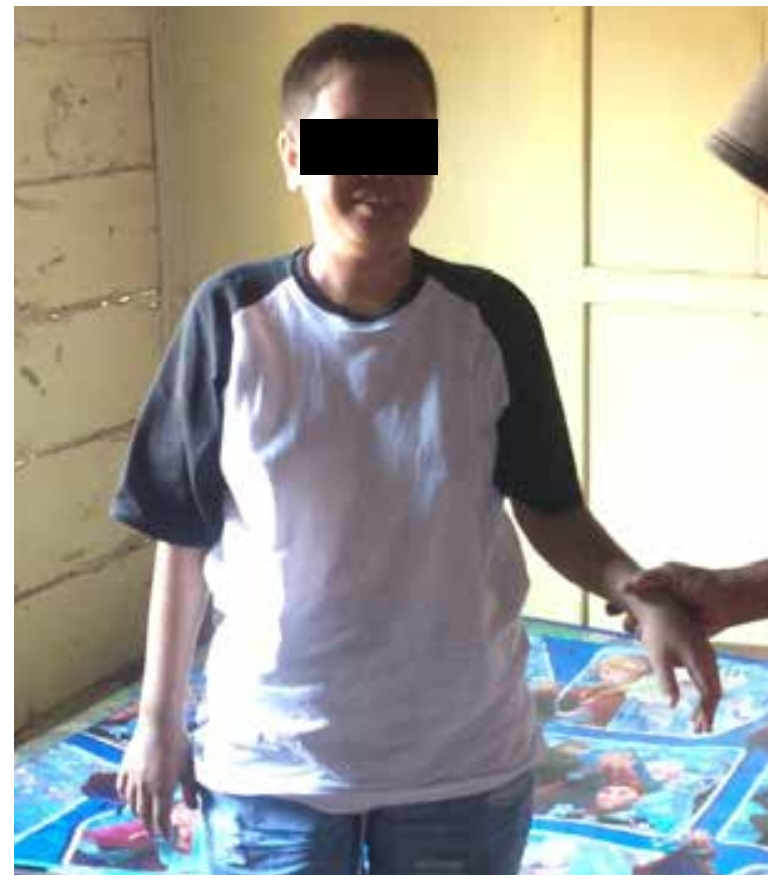

Figure 3. $5^{\text {th }}$ Weeks Post Craniotomy

\section{DISCUSSION}

Based on a study by Lehman et al, 1978 and other studies, the common symptom of cancer patients associated with the need for treatment in rehabilitation showed $35 \%$ with general weakness, $30 \%$ with reduced Capability in conducting daily activities (activities of daily Living, ADL), $30 \%$ with pain, and $25 \%$ with the difficulty of ambulation. Other issues include: speech disorders, swallowing, respiration, neurological disorders, skin problems, nutritional deficiencies, lymphedema, bone problems, and psychological disorders. ${ }^{5}$ Some factors related to the need for rehabilitation treatment are the length of time after the diagnosis of cancer is established, the presence of metastasis, stage cancer, and cancer therapy. ${ }^{7}$ To be able to restore these functions as optimally as possible and improve the patient's quality of life, early and ongoing rehabilitation interventions should be given. Interventions can be physical and occupational therapies, orthotics tools, and other assistive devices. ${ }^{19,20}$

The majority of cancer patients have functional problems related to self-care, mobility, and transitioning to previous lifestyles. Rehabilitation in cancer patients can be broadly defined as a maximum recovery on physical, psychological, social, vocational, recreational, and economic functions within the boundaries caused by the cancer or the effects of therapy. In order to achieve that optimal function, it takes a solid cooperation between members of the interdisciplinary cancer rehabilitation team. ${ }^{19}$

The goal of rehabilitation is to increase/restore the patient's independence with an emphasis on daily activities/ADL, mobility, cognitive function, and communication. Interventions can be applied at all stages of the disease, but the goal of rehabilitation adjusts according to the problem faced by the patient. Rehabilitation programs need to be initiated from the start to achieve goals, prevent complications and achieve better functional outcomes. ${ }^{6}$

Physical disorders experienced by cancer patients can be derived from tissue destruction caused by the cancer itself, immobilization and inactivity, or because of definitive therapies such as surgery, radiation and chemotherapy. ${ }^{19}$ The problems faced by cancer patients relate to their biological, psychological and social functions, which are the immobilization along with the complications (deconditioning, decubitus, and contracture), myopathy, pathological fractures, neuropathy, swelling of the lymph glands, deep venous thrombosis, and others. ${ }^{20}$ Other areas that also require attention in the field of 
rehabilitation are independent ability, body image, language skills, confidence, sexual function, use of mobility aids, and finances. ${ }^{20}$ Therefore, based on the results of the National Cancer Rehabilitation Conference in 1972, the medical rehabilitation approach to cancer treatment has four main objectives: ${ }^{9}$

Patients with cancer are progressive, not static, so that rehabilitation goals must also be progressive and dynamic, the way is to determine the short-term goals executed precisely and quickly, especially in cases with poor prognosis. Sometimes long-term goals are difficult to determine, at least the mediumterm goals (1-2 months) are examined for some short-term goals (day or week).

\section{CONCLUSION}

Rehabilitation Program was improved pain sensation, memory, and mobilization in post craniotomy GBM patient.

\section{REFERENCES}

1. Louis N, Perry A, Reifenberge RG, von Deimling A, Figarella-Branger D, Cavenee WK, et al. The 2016 World Health Organization classification of tumors of the central nervous system: A summary. Acta Neuropathol. 2016;131:803-20.

2. Ostrom QT, Gittleman H, Farah P, Ondracek A, Chen Y, Wolinsky Y, et al. CBTRUS statistical report: Primary brain and central nervous system tumors diagnosed in the United States in 2006-
2010. Neuro Oncol.2013;15 Suppl:2ii-56.

3. Koshy M, Villano JL, Dolecek TA, Howard A, Mahmood U, Chmura SJ, et al. Improved survival time trends of glioblastoma using the SEER 17 population-based registries. J Neuro Oncol. 2012;107(1):207-12.

4. Stupp R, Mason WP, van den Bent MJ, Weller M, Fisher B, Taphoorn MJ, et al. Radiotherapy plus concomitant and adjuvant Temozolomide for glioblastoma. N Engl J Med. 2005;352:987-96.

5. Ohgaki H, Kleihues P. The definition of primary and secondary glioblastoma Clin Cancer Res. 2013; 15;19(4):764-72. doi: 10.1158/1078-0432.CCR-12-3002.

6. Bartolo M, Zucchella C, Pace A, Lanzetta $\mathrm{G}$, Vecchione $\mathrm{C}$, Bartolo $\mathrm{M}$, GrilleaG, Serrao M, Tassorell C, Sandrini G, Pierelli F. Early rehabilitation aftersurgery improves functional outcome in inpatients with brain tumours. JNeurooncol. 2012; 107: 537-44.

7. Kim YM, Kim D, Chun MH, Jeon J, Yun GJ, Lee MS. Cancer Rehabilitation: Experience, Symptoms, and Needs. J Korean Med Sci. 2011; 26: 619-624.

8. Thakkar J, Dolecek TA, Horbinski C, Ostrom QT, Lightner DD, Barnholtz-Sloan JS, et al. Epidemiologic and molecular prognostic review of glioblastoma. Cancer Epidemiol. Biomarkers Rev. 2014;23(10):1985-96.

9. Fu JB1, Raj VS2, Guo Y3. A Guide to Inpatient Cancer Rehabilitation: Focusing on Patient Selection and Evidence-Based Outcome. PM R. 2017;9(9S2):S324-S334. 
doi: 10.1016/j.pmrj.2017.04.017.s.

10. Wing JR. Therapeutic Modalities in Cancer. In: Stubblefield MD, O’Dell MW, eds. Cancer Rehabilitation: Principles and Practice. New York: Demos Medical. 2009; 797-802.

11. Song W, Ruder AM, Hu L, Li Y, Ni R, Shao W, et al. Genetic epidemiology of glioblastoma multiforme: Confirmatory and new findings from analyses of human leukocyte antigen alleles and motifs. PLoS One. 2009. 23;4(9):e7157.

12. Gately L, McLachlan SA, Dowling A, Philip J. Life beyond a diagnosis of glioblastoma: a systematic review of the literature. J Cancer Surviv. 2017;11(4):447-452. doi: 10.1007/ s 11764-017-0602-7.

13. Taylor A, Karajannis MA, Harter DH. Glioblastoma multiforme: State of art and future therapeutics. Surg Neurol Int. $2014 ; 5: 64$.

14. Ohgaki H, Kleihues P. The definition of primary and secondary glioblastoma. Clin Cancer Res. 2013;19:764-72.

15. Gately L, McLachlan SA, Dowling A, Philip J. Life beyond a diagnosis of glioblastoma: a systematic review of the literature. $J$ Cancer Surviv. 2017;11(4):447-452. doi: 10.1007/ s11764-017-0602-7.

16. Zorzan M, Giordan E, Redaelli M, Caretta A, Mucignat-Caretta C. Molecular targets in glioblastoma. Future Oncol. 2015;11(9):1407-20. doi: 10.2217/ fon. 15.22 .

17. Olar A1, Aldape KD. Using the molecular classification of glioblastoma to inform personalized treatment. J Pathol. 2014 ;232(2):165-77. doi: 10.1002/path.4282.

18. Fu JB, Morishita S, Yadav R. Changing Paradigms in the Rehabilitation of Inpatients with Brain Tumors. Curr Phys Med Rehabil Rep. 2018;6(2):115-120. doi: 10.1007/s40141-018-0182-0.

19. Roberts PS, Nuño M, Sherman D, Asher A, Wertheimer J, Riggs RV, et.al.The impact of inpatient rehabilitation on function and survival of newly diagnosed patients with glioblastoma. PM R. 2014; 6(6):514-21.

20. Okamura H. Importance of Rehabilitation in Cancer Treatment and Palliative Medicine. Jpn J Clin Oncol 2011;41(6)733-738. 